\title{
Composição química e degradabilidade in situ de silagens de capim-Marandu com farelo de babaçu ${ }^{1}$
}

\author{
Chemical components and degradability in situ of Marandu grass silages with \\ increasing levels of babassu meal
}

COSTA, Clésio dos Santos ${ }^{2 *}$; RODRIGUES, Rosane Cláudia ${ }^{2}$; ARAÚJO, Ricardo Alves de ${ }^{3}$; SOUZA, Francisco Bruno Ferreira de ${ }^{4}$; SANTOS, Francisco Naysson de Souza $^{5}$; COSTA, Francivaldo Oliveira ${ }^{6}$; RODRIGUES, Marcônio Martins ${ }^{2}$; MENDES, Sanayra da Silva ${ }^{7}$

${ }^{1}$ Projeto Financiado pela FAPEMA.

${ }^{2}$ Universidade Federal do Maranhão, Centro de Ciências Agrárias e Ambientais, Programa de PósGraduação em Ciência Animal, Chapadinha, Maranhão, Brasil.

${ }^{3}$ Programa de Doutorado Integrado em Zootecnia UFC/UFRPE/UFPB, Departamento de Zootecnia, Fortaleza, Ceará - Brasil. Bolsista Capes/Embrapa.

${ }^{4}$ Universidade Federal do Maranhão, Centro de Ciências Agrárias e Ambientais, discente do curso de Agronomia, Chapadinha, Maranhão, Brasil.

${ }^{5}$ Universidade Federal do Ceará, Programa de Pós-Graduação em Zootecnia, Ceará, Brasil.

${ }^{6}$ Zootecnista, Mestre em ciência animal, Chapadinha, Maranhão, Brasil.

${ }^{7}$ Zootecnista.

*Endereço para correspondência: clesiosantzoo@gmail.com

\section{RESUMO}

Objetivou-se avaliar a composição química e a degradabilidade in situ de silagens de capimMarandu com farelo de babaçu. Adotou-se delineamento inteiramente casualizado com cinco tratamentos $(0,5,10,15$ e $20 \%$ de inclusão de farelo de babaçu com base na matéria natural), com cinco repetições. Foram utilizados silos de PVC, adotando-se pressão de compactação de $550 \mathrm{~kg} / \mathrm{m}^{3}$. Para o ensaio de degradabilidade foi utilizado um ovino mestiço fistulado no rúmen, com delineamento inteiramente casualizado com arranjo em parcelas subdivididas, as silagens representam as parcelas e os tempos de incubação $(6,24,96$ e 120 horas) as subparcelas. $\mathrm{O}$ pH aumentou com a inclusão de farelo de babaçu, verificou-se efeito linear $(\mathrm{P}<0,05)$ sobre o teor de matéria seca em função da adição do subproduto. Observou-se efeito quadrático sobreo teor de proteina bruta, com o valor máximo obtido com a inclusão de $17,16 \%$ de farelo. Os teores da fibra em detergente neutro, fibra em detergente ácido e celulose reduziram com o aumento da inclusão do farelo. A lignina e hemicelulose não foram influenciadas pelo uso do aditivo. $\mathrm{O}$ desaparecimento da matéria seca aumentou com o tempo de incubação. A fração solúvel e o máximo potencial de degradação foram observados nas silagens com inclusão de $20 \%$. O farelo de babaçu comportou-se como ótimo absorvente de umidade, aumentou a proteína e reduziu a fibra, consequentemente, elevou o potencial de degradação das silagens.

Palavras-chave: conservação, fração solúvel, subproduto, Urochloa brizantha

\section{SUMMARY}

This study aimed to evaluate the chemical composition and in situ degradability of Marandu grass silages with bran babassu. It adopted a completely randomized design with five treatments $(0,5,10,15$ and $20 \%$ of babassu meal inclusion based on natural matter) with five repetitions. PVC silos were used, adopting compression pressure of $550 \mathrm{~kg} / \mathrm{m}^{3}$. For the degradability test was used a half-breed sheep fistulated in the rumen, with completely 
randomized design with a split plot arrangement, silages represent parcels and incubation times $(6,24,96$ and 120 hours) the subplots. The $\mathrm{pH}$ increases by including babassu meal, there was a linear effect $(\mathrm{P}<0.05)$ on dry matter content due to the addition of the byproduct. Quadratic effect on the crude protein content, with the maximum value obtained with the inclusion of $17.16 \%$ bran. Fiber neutral detergent, acid detergent fiber and pulp decreased with increasing addition of bran. The lignin and hemicellulose were not affected by the use of the additive. The dry matter disappearance increased with the incubation time. The soluble fraction and the maximum potential degradation were observed in silages with addition of $20 \%$. The babassu meal behaved like great absorbing moisture, increased protein and reduced fiber consequently raised the potential for degradation of silages.

Keywords: conservation, soluble fraction, byproduct, Urochloa brizantha

\section{INTRODUÇÃO}

No Brasil, a principal base da alimentação de ruminantes é a utilização de forragens, aproximadamente 117 milhões de hectares de pastagens cultivadas (MACEDO et al., 2013). Deste quantitativo, cerca de $85 \%$ são formadas com gramíneas do gênero Urochloa, haja vista que são adaptadas a vários tipos de solo, possuem elevado valor nutricional, apresentam alta produção de biomassa, e a grande maioria são resistentes a pragas (KARIA et al., 2006; HEINRICHS et al., 2012). Dentre as gramíneas desse gênero, destaca-se o capim-Marandu (Urochloa brizantha cv. Marandu), como a cultivar mais utilizada para formação de pastagens cultivadas no Brasil, pois apresenta boa adaptação a maioria dos solos tropicais e persistência de produção em períodos de estiagem (RODRIGUES JÚNIOR et al., 2015).

No entanto, a criação de ruminantes a pasto é limitada por um grande problema, que é a escassez de alimento no período seco, gerando perda de peso dos animais. Nesse sentido, a utilização de silagem de gramíneas tropicais é uma alternativa para aumentar a suplementação de alimento no período seco, através da conservação do excedente de forragem do período chuvoso. Todavia, as gramíneas tropicais como o capim-Marandu, apresentam algumas limitações como o baixo teor de carboidratos solúveis, alto poder tampão e o mais limitante, baixo teor de matéria seca (NEGRÃO et al., 2016). Dessa maneira, há de se prever que durante a confecção de silagens de capins tropicais poderá haver um comprometimento do processo fermentativo, causando depreciação do valor nutricional do material ensilado.

Dessa maneira, o uso de aditivos de elevado teor de matéria seca vem sendo estudado visando melhorar o perfil fermentativo das silagens, podendo assim melhorar até mesmo o valor nutricional da silagem, dependendo do subproduto utilizado. Contudo, a maioria dos estudos são com capim-Elefante, havendo assim a necessidade de mais trabalhos com o capim-Marandu, tendo em vista a sua alta utilização nos sistemas pecuários.

O farelo de babaçu é um subproduto oriundo da extração do óleo das amêndoas. $\mathrm{O}$ farelo apresenta elevado teor de matéria seca, podendo garantir alta higroscopicidade. Além disso, tem elevado potencial para ser utilizado na nutrição de assim como reportado no estudo de Xenofonte et al. (2008).

Dada a importância do que foi exposto, objetivou-se avaliar a composição química e a degradabilidade in situ da matéria seca de silagens de capimMarandu aditivadas com farelo de babaçu. 


\section{MATERIAL E MÉTODOS}

O experimento foi conduzido no setor de Forragicultura localizado no Centro de Ciências Agrárias e Ambientais da Universidade Federal do Maranhão, em Chapadinha- MA. A gramínea utilizada foi o capim-Marandu (Urochloa brizantha cv. Marandu), coletada no município de Matinha-MA, tendo como posição geográfica latitude $03^{\circ} 06^{\prime} 55,5^{\prime \prime} \mathrm{S}$ e longitude $45^{\circ} 0$ '40,9'” $\mathrm{W}$.

O capim foi cortado manualmente, rente ao solo, quando apresentava altura média de $0,55 \mathrm{~m}$ e 35 dias de idade de rebrotação. Em seguida foi colocado num galpão coberto para o emurchecimento do mesmo, por um período de seis horas e, posteriormente foi picado em partículas de aproximadamente $2 \mathrm{~cm}$, em máquina forrageira acoplada ao trator. Já o farelo de babaçu foi adquirido de indústria beneficiadora de amêndoas localizada na cidade de Itapecuru-Mirim, leste Maranhense.

O experimento foi conduzido em delineamento inteiramente casualizado com cinco tratamentos: $0,5,10,15,20 \%$ de inclusão de farelo de babaçu com base na matéria natural, com cinco repetições, totalizando 25 unidades experimentais.

$\mathrm{O}$ farelo foi homogeneizado em baldes de capacidade 100L, para facilitar o manuseio e evitar contaminação com solo. Em seguida o material foi acondicionado em silos de PVC com $0,10 \mathrm{~m}$ de diâmetro e $0,50 \mathrm{~m}$ de altura, dotados de adaptados com válvula tipo Bunsen nas tampas para facilitar o escape de gases, provenientes da fermentação. Em cada silo foi colocado em média $3 \mathrm{~kg}$ da mistura fresca, adotando-se uma compactação de $550 \mathrm{~kg} / \mathrm{m}^{3}$. Depois que o material foi misturado, e antes de ser colocado nos silos foi realizada uma coleta de 400g do capim-Marandu e do farelo de babaçu, para posteriores análises químicas (Tabela 1).

Após 60 dias, procedeu-se à abertura dos silos, coletando-se em seguida $500 \mathrm{~g}$ de amostras referentes a cada unidade experimental. Para avaliação da composição química das silagens, após a coleta do material foram submetidas à pré-secagem por 72 horas em estufa de ventilação forçada a $65^{\circ} \mathrm{C}$ e, em seguida, foram moídas em moinho tipo Willey com peneira de $1 \mathrm{~mm}$ para análises bromatológicas e $2 \mathrm{~mm}$ para o ensaio de degradabilidade.

No Laboratório de Forragicultura foram determinados os teores de matéria seca (MS), proteína bruta (PB), fibra em detergente neutro (FDN), fibra em detergente ácido (FDA), hemicelulose (HC), lignina (LIG) e $\mathrm{pH}$ das amostras ensiladas após abertura dos silos, seguindo metodologia descrita por Silva \& Queiroz (2002).

Tabela 1. Composição bromatológica do capim-Marandu e farelo de babaçu antes de serem ensilados

\begin{tabular}{lcc}
\hline Item (\%) & Capim-Marandu (\%) & Farelo de babaçu (\%) \\
\hline Matéria seca & 20,2 & 94,25 \\
Proteína bruta & 7,18 & 16,75 \\
Fibra em detergente neutro & 69,47 & 62,73 \\
Fibra em detergente ácido & 52,74 & 31,69 \\
Lignina & 7,77 & 8,81 \\
Hemicelulose & 16,74 & 31,22 \\
Celulose & 44,97 & 22,98 \\
\hline
\end{tabular}


A degradabilidade da matéria seca (DMS) foi estimada pela técnica in situ, utilizouse um ovino mestiço com peso vivo 60 $\mathrm{kg}$, procedimento este sugerido por Tomich \& Sampaio (2004), em que apenas um animal é suficiente para realizar ensaios com incubação ruminal, o animal foi mantido confinado, recebendo capim-Elefante no cocho. O material moído foi colocado em sacos de náilon medindo $12 \mathrm{x} 8 \mathrm{~cm}$ e com poros de $50 \mu \mathrm{m}$ (NOCEK, 1988). Para o ensaio de degradabilidade utilizou-se o delineamento experimental inteiramente casualizado com arranjo em parcelas subdivididas, nas parcelas as silagens e nas subparcelas os tempos. Os tempos de incubação utilizados foram 6, 24, 96 e 120 horas (SAMPAIO 1995; GOMES et al., 2013).

Após o período de incubação, os sacos foram retirados para lavagem, e secos em estufa de circulação forçada de ar, a $50^{\circ} \mathrm{C}$, por 48 horas. Para determinação do desaparecimento do material no tempo zero os sacos foram lavados em recipiente contendo água fria. Após lavagem os sacos receberam os mesmos procedimentos dos sacos que foram incubados.

A percentagem de desaparecimento de matéria seca (DMS) em cada tempo foi calculada pela proporção de alimento que desapareceu nos sacos após a incubação no rúmen. Para avaliação dos parâmetros de degradação da matéria seca (DMS) foi utilizado o modelo Brody de acordo coma equação de Orskov \& Mcdonald (1979), modificado por Sampaio (1988): $\%$ DegMS=A-Bexp(-C*Tempo), em que: $A=$ degradação potencial da forrageira, se não houvesse tempo de colonização, ou seja, se a $\%$ Deg no tempo zero fosse $0 \%$; $\mathrm{B}=$ percentagem do material depositado no rúmen que será degradado, se não houvesse tempo de colonização; $\mathrm{C}=$ taxa constante de degradação do material remanescente no rúmen em qualquer tempo de incubação.

A degradabilidade efetiva da matéria seca (DEMS) foi calculada supondo-se três taxas de passagens ruminal 2,5 e $8 \% / \mathrm{h}$, por intermédio da equação descrita por Orskov\& Mcdonald (1979): $\mathrm{DE}=\mathrm{a}^{\prime}+$ $\left(b^{\prime} * \mathrm{C} / \mathrm{C}+\mathrm{k}\right), \quad$ em que: $\mathrm{a}^{\prime}=\%$ desaparecimento no tempo zero (Média). b'=A-a'. C=taxa constante de degradação. $\mathrm{k}=$ taxa de passagem.

Inicialmente os dados foram submetidos a teste de normalidade (Crame-Von Misses) e homocedasticidade (Levene) e, atendida as pressuposições, foram submetidas à análise de variância. As análises estatísticas foram realizadas considerando-se um nível de significância de até $5 \%$ de probabilidade através do procedimento PROC GLM do software SAS 9.0 (2002).

\section{RESULTADOS E DISCUSSÃO}

Verificou-se que o $\mathrm{pH}$ das silagens de capim-Marandu foi influenciado $(\mathrm{P}<0,05)$ com a inclusão do farelo de babaçu (Tabela 2). Observou-se aumento, à medida que se incluía o farelo, sendo que, os maiores valores foram registrados com a inclusão de 10 e $20 \%$. Em todas as silagens foram constatados valores de $\mathrm{pH}$ acima do recomendado por McDonald, (1981), que é de 3,8 a 4,2 considerados como ideais para que não haja comprometimento no processo fermentativo. Esse resultado pode estar associado ao fato do elevado teor de proteina ter aumentado o poder tampão das silagens, comprometendo a redução do pH. Vieira et al. (2007), ao trabalharem com silagens de capimElefante com inclusão de farelo de babaçu nos níveis de $0,5,10,15$ e $20 \%$, verificaram aumento nos valores de $\mathrm{pH}$ de 4,17 para 4,72 . 
Rev. Bras. Saúde Prod. Anim., Salvador, v.17, n.4, p.572-583 out./dez., 2016 http://www.rbspa.ufba.br ISSN 15199940

Tabela 2. pH de silagens de capim-Marandu com a inclusão de farelo de babaçu

\begin{tabular}{lcccccc}
\hline \multirow{2}{*}{ Variáveis } & 0 & 5 & 10 & 15 & 20 & CV (\%) \\
\cline { 2 - 6 } & $4,82^{\mathrm{c}}$ & $4,98^{\mathrm{b}}$ & $5,28^{\mathrm{a}}$ & $5,06^{\mathrm{b}}$ & $5,18^{\mathrm{a}}$ & 1,55 \\
\hline $\mathrm{pH}$ & $\mathrm{n}$ &
\end{tabular}

Médias seguidas de letras iguais nas linhas não diferem entre si pelo teste de Duncan a $5 \%$ de probabilidade.

Já na silagem sem aditivo, o maior valor de $\mathrm{pH}$ em relação aos níveis preconizados como ideais é devido ao elevado teor de umidade no material, haja vista, que o tempo que o material foi emurchecido pode não ter sido ideal. Portanto, elevados valores de $\mathrm{pH}$, são indicativo de produção de vários ácidos que comprometem e produzem odores muito forte que podem refletir em redução de consumo, pois, os animais podem rejeitar a silagem.

Observou-se efeito quadrático $(\mathrm{P}<0,05)$, para o teor de proteina bruta (PB) com a inclusão de farelo de babaçu (Tabela 3 ). Através da equação verificou-se que o nível ótimo de inclusão de farelo em silagens de capim-Marandu foi de $17,16 \%$, sendo que, a partir desse nível ocorreu redução na $\mathrm{PB}$. $\mathrm{O}$ farelo apresentou teor de proteina superior ao do capim-Marandu, portanto, influenciou o aumento do nutriente na silagem. Já a redução a partir do nível indicado provavelmente está associada com o aumento do $\mathrm{pH}$, pois, devido ao comprometimento da acidificação da silagem pode ter influenciado no aumento da atividade proteolítica. Considerando-se, que a forma com que ocorre a degradação da proteina é baseada nas mudanças do $\mathrm{pH}$ (McDONALD et al., 1991).

Tabela 3. Composição bromatológica: proteína bruta (PB), matéria seca (MS), fibra em detergente neutro (FDN), fibra em detergente ácido (FDA), hemicelulose (HC), celulose (CEL), lignina (LG) de silagens de capim-Marandu com a inclusão de farelo de babaçu

\begin{tabular}{lcccccc}
\hline \multirow{2}{*}{ Variáveis } & \multicolumn{6}{c}{ Níveis de inclusão (\% na matéria natural $)$} \\
\cline { 2 - 6 } & 0 & 5 & 10 & 15 & 20 & CV $(\%)$ \\
\hline PB & $7,10^{\mathrm{c}}$ & $10,20^{\mathrm{bc}}$ & $14,00^{\mathrm{ab}}$ & $15,06^{\mathrm{a}}$ & $13,66^{\mathrm{ab}}$ & 23,14 \\
MS & $17,80^{\mathrm{e}}$ & $21,04^{\mathrm{d}}$ & $24,95^{\mathrm{c}}$ & $32,57^{\mathrm{b}}$ & $41,07^{\mathrm{a}}$ & 3,20 \\
FDN & $65,45^{\mathrm{ab}}$ & $62,50^{\mathrm{ab}}$ & $59,96^{\mathrm{ab}}$ & $55,41^{\mathrm{bc}}$ & $49,64^{\mathrm{c}}$ & 9,99 \\
FDA & $51,11^{\mathrm{a}}$ & $49,98^{\mathrm{a}}$ & $44,76^{\mathrm{b}}$ & $41,72^{\mathrm{b}}$ & $37,02^{\mathrm{c}}$ & 7,24 \\
HC & $15,23^{\mathrm{a}}$ & $13,02^{\mathrm{a}}$ & $15,20^{\mathrm{a}}$ & $14,34^{\mathrm{a}}$ & $12,62^{\mathrm{a}}$ & 28,42 \\
CEL & $38,87^{\mathrm{ab}}$ & $40,21^{\mathrm{a}}$ & $35,86^{\mathrm{ab}}$ & $33,74^{\mathrm{ab}}$ & $29,94^{\mathrm{b}}$ & 19,47 \\
LG & $9,18^{\mathrm{a}}$ & $9,28^{\mathrm{a}}$ & $8,90^{\mathrm{a}}$ & $11,83^{\mathrm{a}}$ & $10,02^{\mathrm{a}}$ & 41,68 \\
\hline
\end{tabular}

Médias seguidas de letras iguais nas linhas não diferem entre si pelo teste de Duncan a $5 \%$ de probabilidade. $\mathrm{CV}=$ coeficiente de variação

Equação PB: $6,73+1,03 X-0,03 X^{2} R^{2}=0,57$;

Equação MS: $15,88+1,16 \times \mathrm{R}^{2}=0,95$;

Equação FDN: $66,34-0,77 \mathrm{X} \mathrm{R}^{2}=0,51$;

Equação FDA: $52,01-0,72 \mathrm{X} \mathrm{R}^{2}=0,74$. 
Entretanto, vale ressaltar que em todas as silagens o teor de $\mathrm{PB}$ foi superior a $7 \%$, sendo que, o menor valor foi observado na silagem sem farelo $(7,10 \%)$, resultado este que se assemelha ao observado por Araújo et al. (2016), para o capim-Marandu $(7,71 \%)$ proveniente de uma pastagem em regime de monocultura, no período chuvoso. O nível mínimo de proteína na dieta de ruminantes visa com que não ocorra limitação na degradação da fibra pelos microrganismos do rúmen (LAZZARINI et al., 2009), atendendo a exigência mínima para o bom funcionamento dos microrganismos do rúmen.

Observou-se efeito linear crescente para o teor de MS das silagens (Tabela 3), com o aumento de inclusão do farelo de babaçu. Verificou-se que para cada 1\% de inclusão do subproduto ocorreu aumento de 1,6 pontos percentuais de MS da silagem. Este resultado é associado ao fato do farelo de babaçu apresentar maior teor de MS (94,25\%), em relação a gramínea avaliada, portanto, destaca-se assim o efeito higroscópico do farelo. Cândido et al. (2007) e Vieira et al. (2007) ao trabalharem com inclusão de subprodutos de elevado teor de MS em silagens de capim-Elefante, observaram aumento no teor de MS à medida que se adicionou o subproduto.

O menor teor de MS foi observado no tratamento controle (Tabela 3), o que já era de se esperar, tendo em vista que quando se trata de gramíneas tropicais estas apresentam alto teor de umidade. O baixo teor de MS pode também está associado ao fato do capim ter sido cortado em estádio fenológico visando bom valor nutritivo, pois, nesta fase dificilmente se tem uma forragem com altos teores de MS.

O teor de matéria seca é bastante enfatizado como um dos critérios no momento da escolha do material ser ensilado, portanto, é preconizado que para que não haja comprometimento no processo fermentativo as silagens devem apresentar entre 28 a $35 \%$ de matéria seca (McDONALD, 1981). As silagens com 5 e $10 \%$ de inclusão apresentaram valores inferiores ao recomendado, esse resultado pode ter refletido no aumento do $\mathrm{pH}$. Já a silagem com inclusão de $20 \%$ apresentou teor de MS de 41,07\%, valor superior ao indicado. Valores muito altos de MS podem proporcionar fermentações indesejáveis devido a maior dificuldade da compactação, portanto novas práticas de manejo neste caso devem ser administradas, como redução no tamanho da partícula (PEREIRA \& REIS, 2001).

Por outro lado, a silagem com $15 \%$ de inclusão apresentou-se entre os níveis indicados, mesmo assim não foi observado valor de $\mathrm{pH}$ entre 3,8 a 4,2. Mas apresentou valor inferior ao observado nas silagens com 10 e $20 \%$. Outros fatores impediram com que mesmo o teor de matéria seca adequado, o valor de $\mathrm{pH}$ não ter reduzido. Vale lembrar, que a MS é apenas um dos prérequisitos.

$\mathrm{O}$ teor de FDN sofreu efeito $(\mathrm{P}<0,05)$, para comportamento linear negativo (Tabela 3). Observou-se que para cada $1 \%$ de inclusão ocorreu uma redução de 0,77 pontos percentuais no teor de FDN da silagem de capim-Marandu. Este resultado é justificado pelo menor teor de $\operatorname{FDN}(62,73)$ do farelo em relação ao da gramínea $(69,47)$, proporcionando, assim, efeito de diluição no teor da fibra da silagem. Costa et al. (2011), ao trabalharem com silagens de diferentes gramíneas, dentre elas a de capimMarandu com diferentes níveis de inclusão de farelo de milheto, observou redução na FDN, com o aumento dos níveis de inclusão, haja vista, que o 
farelo também apresentava valor inferior ao do capim.

Observou-se efeito $(\mathrm{P}<0,05) \quad$ linear decrescente para o teor de FDA (Tabela 3). Para cada $1 \%$ de inclusão do farelo de babaçu foi registrado redução de $0,72 \%$ no valor de FDA da silagem. A redução é justificada pelo menor teor do farelo em relação ao da gramínea, fato este característico de efeito de diluição. Comportamento semelhante foi observado por Pompeu et al. (2006), ao trabalharem com silagem de capimElefante com inclusão de subproduto de abacaxi, a redução se deve ao menor teor de FDA do resíduo 29,64. Essa redução na fibra em detergente ácido, pode melhorar a digestibilidade $\mathrm{e}$ proporcionar maior absorção dos nutrientes, refletindo, assim, em bom desempenho animal, pois, segundo Cândido et al. (2007), valores de FDA acima de $44 \%$ pode reduzir a digestibilidade. Portanto, vale destacar que valores superiores aos citados foram observados nas silagens sem inclusão e com 5 e 10\% de farelo.

A hemicelulose não foi influenciada $(\mathrm{P}>0,05)$ pela inclusão de farelo de babaçu nas silagens de capim-Marandu (Tabela 3). Os maiores teores de $\mathrm{HC}$ do farelo, não foram suficientes para proporcionar efeitos significativos nas silagens. Este fato pode ser explicado provavelmente por comprometimento no processo fermentativo, haja vista, que a hemicelulose é utilizada como componente fermentescível, sendo assim utilizada para formação de ácidos indesejáveis, devido ao $\mathrm{pH}$ elevado (Tabela 1).

A celulose sofreu efeito significativo entre os níveis de inclusão do farelo de babaçu $(\mathrm{P}<0,05)$, o menor resultado foi verificado na silagem com $20 \%$ de inclusão (Tabela 3). Este resultado pode estar ligado ao menor teor de celulose do farelo de babaçu em relação à gramínea ensilada. Maciel et al. (2008), ao trabalhar com farelo de mandioca como aditivo em silagens de capimElefante com os níveis de inclusão de 0 , $5,10,15$ e $20 \%$ também observaram comportamento semelhante.

A lignina não foi influenciada significativamente $(\mathrm{P}>0,05)$ com a inclusão do farelo nas silagens de capim-Marandu, Pinho et al. (2008) não obteve efeito significativo com a inclusão de farelo de mandioca nos níveis de $0,4,8$ e $12 \%$ de inclusão em silagens de capim-Elefante, submetidas ao emurchecimento e não emurchecimento sobre a lignina. Quando se trata de lignina a literatura não apresenta resultados conclusivos em apontar qual o nível adequado de lignina para a alimentação de ruminantes, o certo é que altos teores prejudicam a digestibilidade do alimento.

$\mathrm{Na}$ Figura 1, pode-se observar que houve efeito linear $(\mathrm{P}<0,05)$ para os tempos de 6, 24 e 120 horas de incubação. Já para o tempo de 96 horas foi verificado efeito quadrático. Verificando-se todos os tempos de incubação fica nítido que no tempo de 6 horas apresentou 0 menor desaparecimento de MS em todos os níveis de inclusão de farelo de babaçu. O que já era esperado, pois neste espaço de tempo estava ocorrendo a colonização pelas bactérias no alimento, o menor desaparecimento no tempo de 6 horas também foi observado por Rêgo et al. (2008), ao trabalharem com subproduto de manga em adição a silagens de capim-Elefante. No tempo de 6, 24 e 120 horas foi registrado um aumento no desaparecimento da matéria seca de 0,48, 0,66 e 0,92\% para cada $1 \%$ de inclusão do farelo de babaçu, respectivamente.

Observa-se que com o aumentar do tempo de incubação, proporciona uma 
Rev. Bras. Saúde Prod. Anim., Salvador, v.17, n.4, p.572-583 out./dez., 2016 http://www.rbspa.ufba.br

elevação na taxa de desaparecimento da MS, comportamento semelhante foi observado por Rêgo et al. (2010), quando avaliaram o subproduto do urucum em adição de silagens de capim-Elefante. Este resultado está associado ao fato do maior contato do material com o ambiente ruminal, possibilitando assim maior tempo para que as bactérias conseguissem degradar o alimento.

A fração solúvel (a') das silagens aumentou à medida que se adicionou $\mathrm{o}$ farelo (Tabela 4). Este resultado pode ser explicado pela redução no teor de fibra das silagens com a inclusão do subproduto, proporcionando assim maior solubilidade da MS.

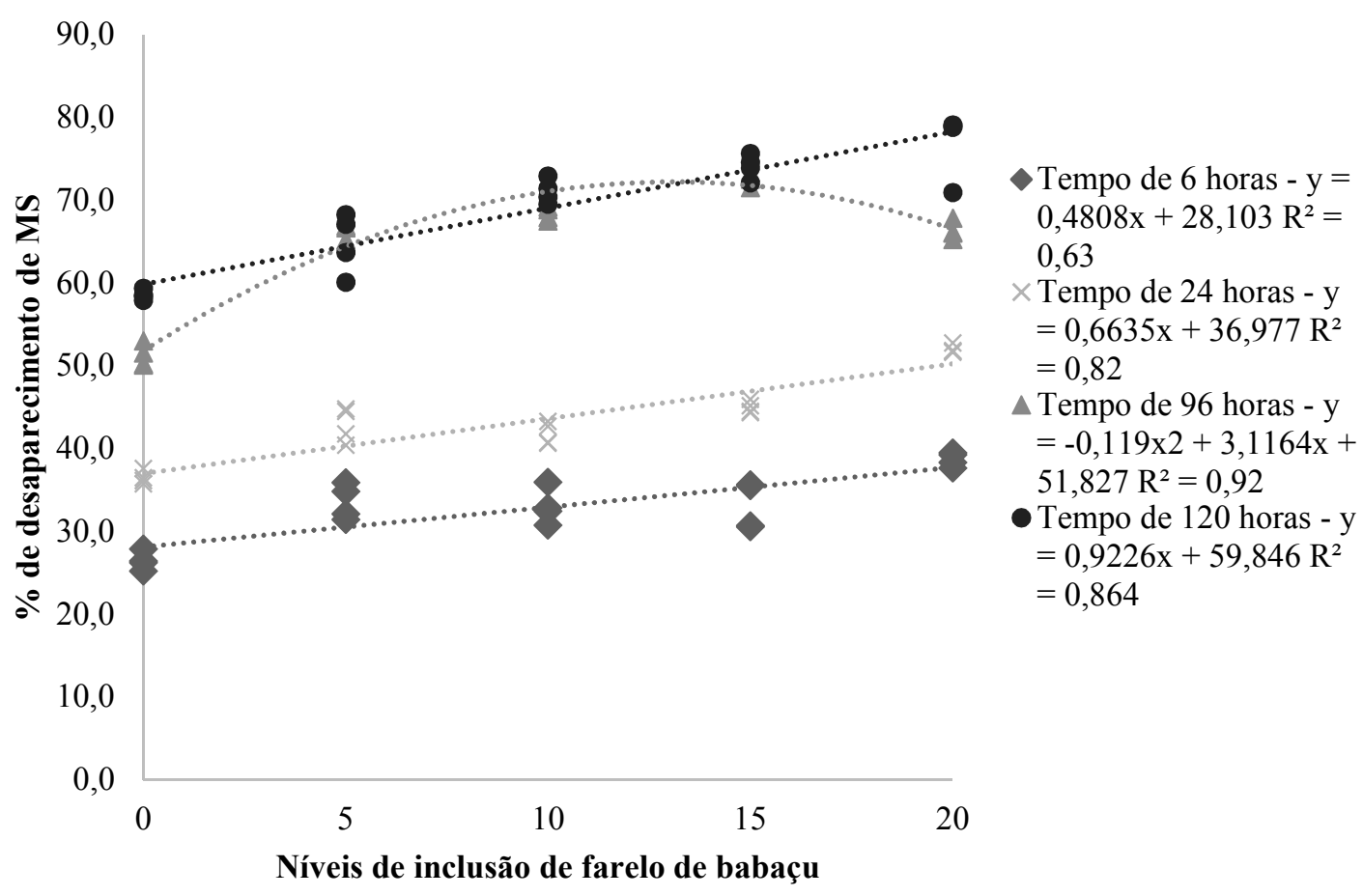

Figura 1. Desaparecimento da matéria seca em cada tempo de incubação em função dos níveis de inclusão do farelo de babaçu

Tabela 4. Fração solúvel (a') e degradabilidade efetiva (DE), de silagens de capimMarandu aditivadas com farelo de babaçu

\begin{tabular}{lcccc}
\hline \multirow{2}{*}{$\begin{array}{l}\text { No de inclusão de } \\
\text { farelo de babaçu }\end{array}$} & Fração solúvel (a) & \multicolumn{3}{c}{ Degradabilidade efetiva } \\
\cline { 3 - 4 } & & 2 & 5 & 8 \\
\cline { 3 - 4 } Matéria seca & & 35,76 & 26,77 & 23,69 \\
\hline 0 & 17,42 & 43,05 & 31,42 & 26,81 \\
5 & 16,18 & 42,96 & 30,78 & 26,57 \\
10 & 17,94 & 48,46 & 35,50 & 30,54 \\
15 & 19,43 & 44,82 & 32,82 & 28,60 \\
\hline
\end{tabular}


A degradabilidade efetiva (DE) aumentou com a inclusão do subproduto (Tabela 4). Estes elevados valores nos tratamentos com maiores níveis de inclusões se devem ao menor teor de fibra das silagens decorrente do efeito de diluição proporcionado pela inclusão do farelo de babaçu. A degradabilidade efetiva também diminuiu à medida que aumentou a taxa de passagem, esse resultado é devido ao menor tempo que o alimento permanece no rúmen, reduzindo assim, o tempo com que os microrganismos ruminais possam atuar. Observa-se que os potenciais de degradação registrado na curva de degradação da matéria seca (Figura 2), foi maior em todas as silagens com adição do farelo de babaçu em relação à silagem do capim-Marandu sem aditivo. $\mathrm{O}$ maior potencial foi observado com inclusão de $20 \%$, esse comportamento é justificado pela redução do teor de FDN devido a inclusão do subproduto. Bezerra et al. (2015), ao trabalharem com silagens de capim-Elefante aditivadas com farelo de milho, verificou que com a inclusão de $20 \%$ apresentou maior potencial de degradação.

Quanto à taxa de degradação (c), foi verificado os maiores valores nas silagens com 5, 15 e 20\% de inclusão de farelo de babaçu. As taxas de todas silagens apresentaram valores abaixo do recomendado por Sampaio (1988), para alimentos de boa qualidade, pois quando se trabalha com alimentos de origem vegetal os mesmos apresentam taxa de degradação satisfatória entre $2 \mathrm{a}$ $6 \% / \mathrm{h}$.

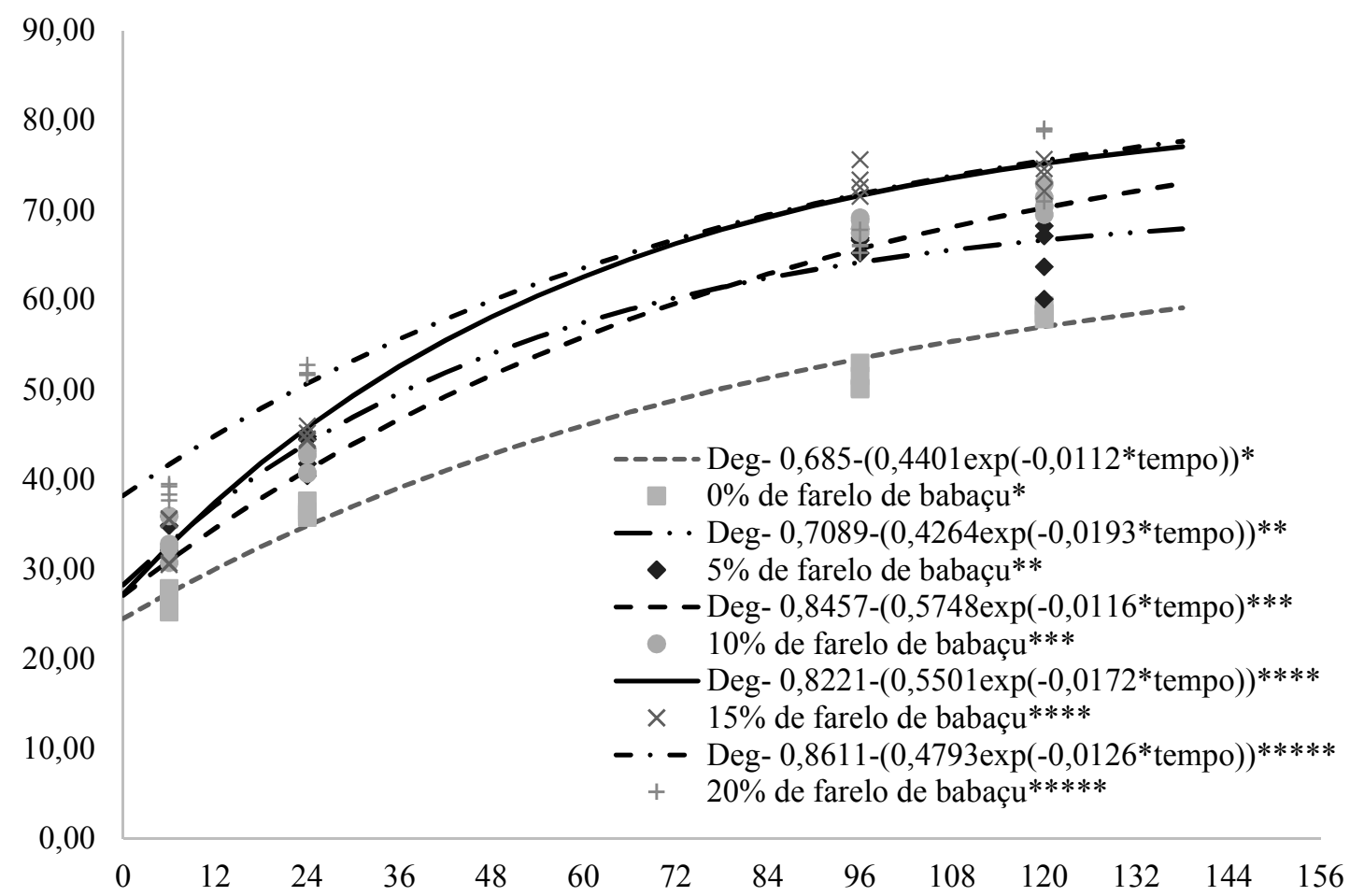

Figura 2. Degradabilidade da matéria seca (MS) de silagens de capim-Marandu aditivadas com farelo de babaçu. Estimada pela equação: Deg= A-Bexp (-c*tempo), sem inclusão de farelo $(*), 5 \%$ de inclusão $(* *), 10 \%$ de inclusão (***), $15 \%$ de inclusão $(* * * *)$ e $20 \%$ de inclusão de farelo de babaçu $(* * * * *)$ 
Rev. Bras. Saúde Prod. Anim., Salvador, v.17, n.4, p.572-583 out./dez., 2016 http://www.rbspa.ufba.br ISSN 15199940

A inclusão de farelo de babaçu apresenta características satisfatórias em silagens de capim-Marandu, como aumento no teor matéria seca, redução nos teores de FDN, FDA, celulose e aumento no teor de proteina até a inclusão de $17,6 \%$ de farelo de babaçu. A inclusão do farelo proporcionou melhorias na degradação da matéria seca das silagens de capim-Marandu. No entanto, não foi eficaz quanto á redução do $\mathrm{pH}$ da silagem, sendo necessário mais estudos com silagens de capim-Marandu.

\section{REFERÊNCIAS}

ARAÚJO, R.A.; RODRIGUES, R.C.; COSTA, C.S.; LANA, R.P.; SANTOS, F.N.S.; LIMA, A.J.T.; RODRIGUES, M.M. Forage intake and performance of cattle in silvopastoral systems and monoculture of Marandu in PreAmazon region.African Journal of Agricultural Research, v.11, n.20, p.1849 -1857, 2016.

BEZERRA, H.F.C.; SANTOS, E.M.; OLIVEIRA, J.S.; CARVALHO, G.G.P.; CASSUCE, M.R.; PERAZZO, A.F.; FREITAS, D.S.S.; SANTOS, V.S. Degradabilidade ruminal in situ de silagens de capim-elefante aditivadas com farelo de milho e inoculante da microbiota autóctone. Revista

Brasileira Saúde e Produção Animal [online], v.16, n.2, p.265-277, 2015.

CÂNDIDO, M.J.D.; NEIVA, J.N.M.; RODRIGUEZ, N.M.; FERREIRA, A.C.H. Características fermentativas e composição química de silagens de capim elefante contendo subproduto desidratado do maracujá. Revista Brasileira de Zootecnia, v.36, n.5, p.1489-1494, 2007. Supl..
COSTA, K.A.P.; GUIMARÃES, K.C.; SEVERIANO, E.C.; ASSIS NETO, J.M.; CRUNIVEL, W.S.; GRACIA, J.F.; SANTOS, N.F. Silage quality of Brachiaria brizantha cultivars ensiled with different levels of millet meal. Arquivo Brasileiro de Medícina Veterinária e Zootecnia, v.63, n.1, p.188-195, 2011.

GOMES, G.M.F; VASCONCELOS, A.M.; EGITO, A.S.; LIMA, A.R.; CARNEIRO, J.C.; LANDIM, A.V.; FONTELES, N.L.O.; SALLES, H.O. Degradabilidade in situ do bagaço de cana-de-açúcar para pequenos ruminantes de raças naturalizadas do Nordeste brasileiro. Arquivos Brasileiros de Medicina Veterinaria e zootecnia, v.65, n.6, p.1792-1800, 2013.

HEINRICHS, R.; SOARES FILHO, C.V.; CRUCCIOLI, C.; FIGUEIREDO, P.A.M. de; FRUCHI, V.M.; KODEL, F.J.; RODRIGUES, T.A. Doses and sources of nitrogen fertilizer and their effects on soil chemical properties and forage yield of Brachiaria brizantha cv. Xaraés. Semina: Agrárias, v.33, n.5, p.1747-1756, 2012.

KARIA, C.T.; DUARTE, J.B.; ARAÚJO, A.C.G. de. Desenvolvimento de cultivares do gênero Brachiaria Griseb. no Brasil. Planaltina: Embrapa Cerrados, 2006. 57p. (Documentos, 163).

LAZZARINI, I.; DETMANN, E.; SAMPAIO, C.B.; PAULINO, M.F.; VALADARES FILHO, S.C.;SOUZA, M.A.; OLIVEIRA, S.A. Dinâmicas de trânsito e degradação da fibra em detergente neutro em bovinos alimentados com forragem tropical de baixa qualidade e compostos nitrogenados. Arquivo Brasileiro de Medicina Veterinária e Zootecnia, v.61, p.635-647, 2009. 
Rev. Bras. Saúde Prod. Anim., Salvador, v.17, n.4, p.572-583 out./dez., 2016 http://www.rbspa.ufba.br

MACIEL, R.P.; NEIVA, J.N.M.; OLIVEIRA, R.C.; ARAÚJO, V.L.; LÔBO, R.N.B. Características fermentativas e químicas de silagens de capim-elefante contendo subproduto da mandioca. Revista Ciência Agronômica, v.39, n.1, p.142-147, 2008.

McDONALD, P. The biochemistry of silage. New York: John Eilley\& Songs, 1981. $226 \mathrm{p}$.

McDONALD, P.; HENDERSON, A.R.; HERON, S.J.E. The biochemistry of silage. 2th ed. Marlow: Chalcombe Publication, 1991.340p.

MACEDO, M.C.M.; ZIMMER, A.D.; KICHEL, A.N.; ALMEIDA, R.G.; ARAUJO, A.R.Degradação de pastagens, alternativas de recuperação e renovação, e formas de mitigação. In: ENCONTRO DE ADUBAÇÃO DE PASTAGENS DA SCOT CONSULTORIA - TEC FÉRTIL, 1., 2013, Ribeirão Preto,SP. Anais... Bebedouro: Scot Consultoria, 2013. p.158-181.

NOCEK, J.E. In situ and other methods to estimate ruminal protein and energy digestibility: A review. Journal of Dairy Science, v.71, n.8, p.2051-2069, 1988.

NEGRÃO, F.M.; ZANINE, A.M.; SOUZA, A. L.; CABRAL, L.S.; FERREIRA, D.J.; DANTAS, C.C.O. Perdas, perfil fermentativo e composição química das silagens de capim Brachiaria decumbens com inclusão de farelo de arroz. Revista Brasileira de Saúde e Produção Animal [online], v.17, n.1, p.13-25, 2016.

ØRSKOV, E.R.; McDONALD, I. The estimation of protein degradability in the rumen from incubation measurements weighed according to rate of passage. Journal of Agricultural Science, v.92, p.499-503, 1979.
PINHO, B.D.; PIRES, A.J.V.; RIBEIRO, L.S.O.; CARVALHO, G.G.P. Ensilagem de capim-elefante com farelo de mandioca. Revista Brasileira Saúde e Produção Animal, v.9, n.4, p. 641-651, 2008.

PEREIRA, J.R.A.; REIS. R.A. Produção de silagem pré-secada com forrageiras temperadas e tropicais. In: SIMPÓSIO SOBRE PRODUÇÃO E UTILIZAÇÃO DE FORRAGENS CONSERVADAS, Maringá, 2001. Anais... Maringá: Universidade Estadual de Maringá, 2001. p.64-86

POMPEU, R.C.F.F.; NEIVA, J.N.M.; CÂNDIDO, M.J.D.; OLIVEIRA FILHO, G.S.; AQUINO, D.C.; LÔBO, R.N.B. Valor nutritivo de silagens de capimelefante (Pennisetum purpureum Schum.) com adição de subprodutos do processamento de frutas tropicais. Revista Ciência Agronômica, v.37, n.1, p.77-83, 2006.

RÊGO, A.C.; CÂNDIDO, M.J.D.; PEREIRA, E.S.; CAVALCANTE, M.A.B.; FEITOSA, J.V.; GOMEZ, F.H.T.; NEIVA, J.N.M.; RÊGO, M.M.T. Degradabilidade Ruminal In Situ de Silagens de Capim-Elefante com Adição de Subproduto da Manga. Revista Cientifica de Produção Animal, v.10, n.1, p.28-36, 2008.

RÊGO, A.C.; CÂNDIDO, M.J.D.; PEREIRA, E.S.; FEITOSA, J.V.; RÊGO, M.M.T. Degradação de silagens de capimelefante contendo subproduto do urucum. Revista Ciência Agronômica, v. 41, n. 3, p. 482-489, 2010.

REZENDE, V.M.; PAIVA, P.C.A.; BARCELOS, A.F.; TEIXEIRA, J.C.; NOGUEIRA, D.A. Degradabilidade ruminal das silagens de capim-Napier produzidas com diferentes níveis de farelo de "batata diversa". Revista Ciência tecnologia, v.31, n.2, p.485-491, 2007. 
Rev. Bras. Saúde Prod. Anim., Salvador, v.17, n.4, p.572-583 out./dez., 2016 http://www.rbspa.ufba.br

RODRIGUES JÚNIOR, C.T.R.; CARNEIRO, M.S.S.; PEREIRA, E.S.; RODRIGUES, B.H.N.; COSTA, N.L.; PINTO, M.S.C.; ANDRADE, A.C.; PINTO, A.P.; FOGAÇA, F.H.S.; CASTRO, K.N.C. Produção e composição bromatológica do capimMarandu em diferentes épocas de diferimento e utilização. Semina: Ciências Agrárias, v.36, n.3, p.21412154, 2015. Suplemento 1.

SAMPAIO, I.B.M. Experimental Designs and Modeling Techniques in the Study of Roughage Degradation in Rumen and Growth of Ruminants. 1988. 214 f. Tese (Doutorado em Zootecnia) - University of Reading, Reading.

SAMPAIO, I.B.M; PIKE, D.J.; OWEN, E. Optimal design for studying dry matter degradation in the rumen. Arquivos Brasileiro de Medicina Veterinaria e Zootecnia, v.47, p.373-383, 1985.

SAS INSTITUTE. SAS user'sguide: statiscs. Version 9. Cary, 2002.

SILVA, D.J.; QUEIROZ, A.C. Análise de alimentos: métodos químicos e biológicos. 3.ed. Viçosa, MG: UFV, 2002. 235p.

TOMICH, T.R.; SAMPAIO, I.B.M. A new strategy for the determination of forage degradability with an in situ technique through the use of one fistulated ruminant. Journal of Agricultural Science, v.142, p.589-593, 2004.

VIEIRA, M.M.M.; CAVALCANTE, M.A.B.; NEIVA, J.N.M.; CÂNDIDO, M.J.D. Valor nutritivo de silagens de capim elefante contendo níveis de farelo de babaçu. Archivos de Zootecnia, v.56, n.214, p.257-260. 2007.
XENOFONTE, A.R.B.; CARVALHO, F.F.R.; BATISTA, A.M.V.; MEDEIROS, G.R.; ANDRADE, R.P.X. Desempenho e digestibilidade de nutrientes em ovinos fistulados com rações contendo farelo de babaçu. Revista Brasileira de Zootecnia, v.37, n.11, p.2063-2068, 2008.

Data de recebimento: 27/02/2015

Data de aprovação: 31/08/2016 